"The Limits of Animal Intelligence."

Ir is with much pleasure that I have read Prof. Lloyd Morgan's letter, wherein he tells us that "the power of cognizing relations, reflection, and introspection" appears to him to mark a "new departure" in the ascending scale of psychical activities. His term, "feeling of awareness of certain relationships," is new to me, however, and seems to demand a further distinction. I am generally aware, in a vague way, of what I may be doingthat is to say I have a certain consciousness of it. But every now and then I find that $I$ have done, without consciousness, things which I could not have done without the exercise of my sensitive faculty, or without the guidance of bodily movement, by that faculty.

I most cordially concur in the Professor's desire that the investigations to which he refers should be accompanied by "calm, temperate, and impartial discussion" founded on observation and experiment. I, as well as Prof. Lloyd Morgan, have long carried on such observations and experiments, and it is on them that are founded what I have written on "Our lower and higher mental powers" in chapters xiv. and xv. of my book "On Truth." To them I may perhaps be permitted to direct the Professor's attention, since be is engaged with a work on Comparative Psychology. I have as little wish to dogmatize as has Prof. Lloyd Morgan, and am perfectly ready and willing to recognize the true rationality of any animal whenever I obtain evidence thereof. My assertion of the exclusive rationality of man has been represented as due to other causes than what I deem to be the weight of scientific evidence. Such is an utter mistake. To admit that animals possess intellect would neither be repugnant to my feelings nor confict with any other of my convictions. As yet I hold all animals to be irrational, simply because I have met with, in them, nothing inexplicable by what the Professor calls "simple awareness" and what I call related feelings. All prejudice should indeed be eliminated from scientific inquiry, but such can hardly be the case with any one who starts from an a priori "standpoint of evolution "in the sense that he holds discontinuities in nature-real "new departures"-to be impossible.

The Professor says : "In conclusion I must be allowed to say that the phrases 'differences in kind ' and 'differences in degree' savour somewhat of mere Academic discussion." Nevertheless there really are differences of kind, and such differences are themselves different in kind from mere differences of degree. $\mathrm{He}$ would, of course, allow that the difference between the Binomial Theorem and the Bouquet of Chateâu d'Yquem is one " of kind," as also that between solving the Pons asinorum and riding Equus asinus. I am convinced there are also psychical differences of kind, and I have become so convinced (in spite of having started with a contrary opinion) through experiments and observations.

Hurstcote, September 6.

St. George Mivart.

\section{The Theory of the Telephone.}

IN a paper in this month's Phil. Mag. I ventured to publish an explanation of the fact that in the telephone it is necessary for the diaphragm to be situated in a permanent magnetic field.

Since then my attention has been called to a paper (The Electrician, Feb. I I, I887, p. 302) by Mr. Oliver Heaviside, in which he has given a very complete theory of the question at issue.

I hasten to express my regret that I had not met with this paper in time.

Physical Laboratory, Trinity College, Dublin.

\section{Crater-like Depressions in Glaciers.}

In the note on the St. Gervais Catastrophe (NATURE of September I) I read that a crater-like depression had been tound in the Tête Rousse Glacier. As such depressions are quite exceptional occurrences in European glaciers, it may be of interest to note that I found several holes of a similar kind in the great Tasman Glacier in New Zealand. One of these reached - like the Tête Rousse one-apparently to the bottom, the others, which were from 150 feet to 300 feet deep, did not. The walls of these "craters" were not vertical but above only $45^{\circ}$, the incline increasing below. Till now I have considered these funnel-shaped depressions as immensely widened "Glaciermills," I Referred to on p. 266 of NATURE for July 21 , 1892 . NO. 1194 , VOL. 46] but after the observation on the Tête Rousse it seems to me not improbable that these holes on the Tasman were also originally caused by subglacial collapse.

R. VON LENDENFELD.

\section{CHOLERA: PREVENTIONAND VACCINATION.}

THE epidemic of cholera with which this country

is threatened seems likely to test very completely the means for the prevention of its spread which have been devised as the result of the extended experience of some of the ablest hygienists. The working out of the history of an epidemic disorder must necessa rily be extended over a prolonged period of time, for it is dependent on the researches not only of the clinical observer, but of the pathologist and the bacteriologist and of those who devote themselves to the difficult study of the march of epidemics. The development of such researches is closely allied to the advance of science generally, and although there is at any one period a large admixture of "fashion" in the opinions held by experts, yet in time this fades, and the truth is established. It cannot be too clearly stated that the best measures for the prevention of an epidemic disorder can only be devised when we possess an accurate knowledge of the infective agent of the disease (bacillus or not, as the case may be), of its lifehistory, of its varying degrees of virulence, and the mode of entrance into the body, of the conditions under which it multiplies, and of the changes which it produces in the human body.

In the case of cholera our knowledge is not yet complete. Clinical observers many years ago showed that the infective agent was present in the peculiar evacuations passed by the cholera patient, and it was further found that these evacuations were the means of contaminating the water supply of a locality, and so causing the spread of the disease in the community. These two facts have been established beyond doubt. The exact nature of the living infective agent is not, however, so well ascertained. It was in 1884 that Koch described the Vibrio Cholerce A siatice as constantlypresent in the evacuations of cholera patients, but he was unable to prove that it was the cause of the disease, owing to the insusceptibility of animals to cholera. It was shown that the vibrio was present also in the intestinal walls, but it was never found in the organs of the body. The work of subsequent observers has brought forward fresh facts of importance. It is now known that the cholera vibrio (the comma bacillus) is allied to several other forms which are pathogenic, and that there are several varieties (perhaps twelve) which have been described by Dr. Cunningham. The cholera vibrio is also known to vary greatly in virulence; it is so susceptible to its surroundings that a slight change will diminish its activity and certain conditions will increase its virulence. One method of increasing its activity is by passing it through a series of animals (guinea-pigs); after a certain time the vibrio becomes extremely active and will kill animals very quickly, it is said in even eight hours. With these virulent cultures symptoms have been produced in animals closely resembling those of Asiatic cholera; in the exudation of liquid into the intestines, in the cramps, in the suppression of urine, and in the collapse so well known in the disease in man. There are therefore certain grounds for considering Koch's vibrio as the cause of Asiatic cholera. But the question is not settled : it is not as clear that the vibrio is the cause of Asiatic cholera as that the bacillus anthracis is the cause of anthrax. The probabilities are greatly in favour of this presumption, but the slight doubt existing must be borne in mind when the question of vaccination for cholera is to be considered practically. The doubt that rests on the vibrio as the cause of cholera may be stated shortly in the fact of the existence of allied forms of bacteria which produce similar symptoms, such as the vibrio Metschni- 